\title{
A MULTIPLE LENDER APPROACH TO UNDERSTANDING SUPPLY AND SEARCH IN THE EQUITY LENDING MARKET ${ }^{*}$
}

\author{
Adam C. Kolasinski \\ University of Washington Business School \\ adamkola@u.washington.edu \\ Adam V. Reed \\ Kenan-Flagler Business School, University of North Carolina \\ adam_reed@unc.edu \\ Matthew C. Ringgenberg \\ Kenan-Flagler Business School, University of North Carolina \\ matthew_ringgenberg@unc.edu
}

\begin{abstract}
Although a large body of research has investigated the effects of short sale constraints, very little is understood about the origin of these constraints in the one-trillion-dollar equity lending market. Using a unique database comprising data from twelve lenders, we find significant dispersion in share loan fees across lenders, and we find that the dispersion is increasing in share loan demand and various proxies for search costs, including a stock's illiquidity and the number of small lenders making loans. These findings are consistent with the existence of search frictions between share borrowers and lenders, as Duffie, Garleanu, and Pedersen (2002) suggest. We further analyze the effect of search frictions by examining the response of shorting cost to exogenous shocks in demand. We find that for stocks with moderate demand, loan fees are largely insensitive to demand shocks. However, for stocks with high demand, an increase in demand triples the already higher abnormal loan fees. Our findings help reconcile seemingly conflicting findings in the literature regarding the existence of both small and large effects of shifts in demand on price. We highlight the importance of search costs by showing that the various parameters in firms' share loan supply schedules are closely related to crosssectional differences in search costs. We conclude that short sale constraints could be slackened by the reintroduction of a central clearinghouse of share loans, which would reduce search costs.
\end{abstract}

\footnotetext{
* The authors thank Robert Battalio, Darrell Duffie, Nicolae Garleanu, Jennifer Huang, David Musto, Lasse Pedersen, and seminar participants at the American Finance Association Conference, Barclays Global Investors, the Consortium for Financial Economics and Accounting Conference, the European Finance Association Conference, the IIROC-DeGroote Conference on Market Structure, Texas A\&M, the University of Oregon's Institutional Asset Management Conference, the University of Virginia, and the University of Washington. We are grateful for financial support from the Q Group. Our data provider made this work possible and provided invaluable advice over the course of numerous discussions. Finally, we thank William Frohnhoefer for providing institutional details.
} 
Short sale constraints motivate a large body of theoretical research in asset pricing. In addition, a growing body of empirical work confirms that these constraints have an economically meaningful impact. ${ }^{1}$ While this research suggests that short sale constraints are important, relatively few empirical studies attempt to explain the variation of short sale constraints across stocks, and even fewer seek to provide a motivation for the origin of these constraints.

Short sale constrains can take many forms, but one of the most important is the fee that short sellers pay to borrow shares in the equity lending market. Despite its one-trillion-dollar size, relatively little known about this market because transactions are usually only visible to the two parties directly involved. Furthermore, the equity loan databases employed in the existing literature are provided by individual equity lenders, so researchers have not had an opportunity to draw conclusions about market-wide characteristics. As a result, a number of important questions remain unanswered. How much short selling can take place before borrowing shares becomes expensive? What causes borrowing to become expensive? What are the characteristics of the share lending supply curve? And, finally, how much variation in fees could a borrower expect to see across multiple lenders? We find that the answers to these questions are all related to the presence of search frictions in the equity lending market.

The general dearth of empirical research on the equity lending market is inherently linked to its opacity, and one of the primary goals of this paper is to analyze the effects of this opacity. In one of the few theoretical models of the equity loan market, Duffie, Garleanu, and Pedersen

\footnotetext{
${ }^{1}$ The theoretical literature on short selling includes Miller (1977), Hong and Stein (1999), and Diamond and Verrecchia (1987), and empirical work demonstrating the significant economic impact of short sale constraints includes Geczy, Musto, and Reed (2002), Ofek and Richardson (2003), Asquith, Pathak, and Ritter (2005), and Cao, Dhaliwal, Kolasinski, and Reed (2007).
} 
(2002; hereafter DGP) suggest that search frictions, which result from opacity, give share lenders market power, allowing them to charge fees to short sellers. We examine this model empirically in a number of ways. We identify significant dispersion in loan fees, which is consistent with the existence of search frictions in the share loan market. In addition, using stock characteristics that DGP suggest as proxies for search frictions, we show that search frictions are related to loan fee dispersion. Finally, we find that loan fee dispersion sharply increases as the average loan fee moves from moderate to high levels, consistent with DGP's hypothesis that search frictions are related to the costs of short selling. However, the relation between the average fee and the dispersion in fees is not monotonic: dispersion is also high when the average fee is abnormally low, resulting in a U-shaped pattern.

We also examine how search frictions allow lenders to change their prices in response to exogenous shifts in demand. In the existing literature, some controversy exists regarding the way demand affects prices; some researchers find that lending fees are unresponsive to increases in quantity (e.g., Christoffersen, Geczy, Musto, and Reed (2007)), whereas others find that large positive shifts in the demand for share loans can be manifested in increased lending fees (e.g., Cohen, Diether, and Malloy (2006)). We resolve this apparent paradox by using a nonlinear two-stage least squares method to estimate the share loan supply schedule, and we find that it is non-linear. Most of the time, when the demand for share loans is moderate, the slope of the supply schedule is nearly flat, and lending fees are largely insensitive to quantity demanded, consistent with the results of Christoffersen et al. However, large positive shocks to demand tend to drive quantity into the upward sloping region, where the lending fee is indeed highly sensitive to the quantity demanded, consistent with Cohen et al. To further investigate the 
relation between the supply curve and search frictions, we relate the supply curve parameters to several proxies of search frictions. We conclude that both the level of the loan fee and its sensitivity to quantity demanded are a function of search frictions, further validating the DGP claim that search frictions are at the root of short sale constraints.

The results of this research have important policy implications. Because search frictions have a significant impact on lending fees, it follows that a reduction in these frictions would loosen short sale constraints. One way to reduce search frictions is to introduce a central clearinghouse for share loans, such as the NYSE lending post that was abandoned in the 1930s. Furthermore, there is evidence that short sale constraints reduce market efficiency (e.g., Asquith, Pathak and Ritter (2005) and Boehmer, Jones and Zhang (2008)). Taken together, these results suggest that centralizing the share loan market could significantly improve stock market efficiency.

Our findings also have broader implications for opaque financial markets. The theoretical models we use to motivate our empirical tests need not be limited to the equity lending market. Insofar as their underlying assumptions of agent heterogeneity, search frictions, and the lack of centralized price quoting are consistent with the institutional details of other overthe-counter markets, our results are generalizable to those contexts.

The remainder of this paper proceeds as follows. Section I examines the search cost literature and explores the applicability of search cost models to the equity lending market, with a particular focus on the ability of search frictions to generate short sale constraints, and the 
resulting empirical implications. Section II describes the databases used in this study, and section III characterizes our findings. Section IV presents our summary and conclusion.

\section{Search Frictions and the Share Lending Market}

\section{A. Specialness, Search Frictions, and Price Dispersion}

DGP present a dynamic model in which search frictions limit the frequency at which share lenders and borrowers are able to find one another. Thus lenders, if they have some bargaining power, are able to charge a lending fee to short sellers that is equal to some fraction of the surplus short sellers believe they can gain. Short sellers are willing to pay the fee because if they refuse, they might not be able to find another lender and thus would have to forgo their surplus. Over time, this lending fee declines to zero as short sellers drive down prices to their long-run equilibrium values. The magnitude of the lending fee, often termed specialness, is increasing in lenders' bargaining power, increasing in frictions in the share lending market, and increasing in demand for share loans. While the DGP model is derived in the context of IPOs, the authors indicate that it would produce similar results in the event of a shock to the demand for short selling.

In our investigation of the role of search frictions in the share loan market, we first turn to the industrial organization literature on price dispersion. When there is heterogeneity in seller costs, models in which buyers must search sequentially for a seller generally yield a positive relation between average prices, price dispersion across sellers, and search costs (Reinganum, 
1979; Sirri and Tufano, 1998; Duffie, Garleanu, and Pedersen, 2006; Baye, Morgan, and

Scholten, 2006). The DGP model does not predict dispersion in fees across lenders because it assumes no heterogeneity in lenders' costs of providing share loans (DGP assume lenders' costs are zero). However, in practice it is likely that some heterogeneity in lenders' costs does exist, so if search frictions drive specialness, we would expect an increased average level of specialness to be associated with increased dispersion in specialness across lenders. Using data from multiple lenders, we compute dispersion in specialness across lenders for a given stock at a given point in time. ${ }^{2}$ We then examine the relation of this dispersion to the average specialness in a given day, as well as investigating other proxies for search costs.

\section{B. The Share Loan Supply Curve}

While search frictions are constant in the DGP model, they are not likely to be so in practice. As DGP point out, these frictions are likely to be close to zero when demand for loans is low. In this case, brokers have more lenders than borrowers among their clients, so matching is nearly costless. In addition, brokers have the ability to contact different lenders for information about availability and pricing, and most of the time the lenders with whom they have an existing relationship have an ample supply of most stocks. However, anecdotal evidence indicates that certain stocks may not be available from all lenders, and in these cases we would

\footnotetext{
${ }^{2}$ One natural way to understand the DGP model in the context of heterogeneous search costs is thinking terms of local monopolies. Search frictions give each lender a local monopoly because borrowers have greater difficulty finding the lenders' competitors. When share loan demand is high, search frictions increase the monopoly power of lenders. Furthermore, if there is heterogeneity among lenders, each will have a different monopoly price, so as search frictions increase, we expect more price dispersion.
} 
expect brokers to search for shares. The existence of third-party lenders, or "finders" as in Fabozzi (1997), is evidence for this. In Figure 1 we show the structure of these relationships.

The supply of easily obtainable loans is thus more likely to be exhausted if there is a large shock to the demand for share loans; in such a case, searching for shares will become more difficult and costly. Accordingly, just as search frictions lead to increases in specialness, we expect the share loan supply curve to have a positive slope when demand is high.

On the other hand, if a loan program for a particular stock involves certain fixed costs, then the marginal cost of share loans is likely decreasing at very low levels of quantity, inducing a downward slope in the left-hand portion of the share loan supply schedule. The presence of fixed costs also likely lowers the number of willing lenders when demand is low, potentially giving these lenders some monopoly power. As share loan demand increases from very low to moderate levels, we expect the number of lenders to increase, thereby reducing monopoly power and yielding a downward slope in the left-hand portion of the share loan supply schedule. We thus expect the share loan supply schedule to be non-monotonic, with a downward slope at low quantity levels, a relatively flat slope for moderate quantities, and an upward slope at high quantity levels.

\section{Data}

\section{A. Loan Quantity and Lending Fees}


The data provider for our study is both a market maker in the equity loan market and a data aggregator for major equity lenders. In its role as a market maker, the firm intermediates loans by borrowing from one party and lending to another. As such, our data provider also contributes its own transactions to the database. More importantly for the purposes of this paper, in its role as a data aggregator our data provider collects information about equity loan market conditions from several equity lenders. In particular, the firm provides current and historical stock loan market rates based on live data feeds from equity lenders. These lenders contribute current and historical data about their own loan portfolios in exchange for access to this marketwide information.

Our database consists of historical loan portfolios from twelve lenders. As shown in Table I, the lenders providing data are direct lenders, agent lenders, retail brokers, broker dealers, and hedge funds. The principal owners of the shares that are lent (both directly and through agents) are retail brokerages, pension plans, insurance companies, and mutual funds. These market participants represent $36 \%$ of the securities lenders by number. ${ }^{3}$ In most of the analyses that follow, including the estimation of the supply schedule, we use the sum of outstanding share loans by all lenders, normalized by total shares outstanding, to form our measure of market loan quantity.

We use two separate databases: one database comprises 5,042,056 observations of individual loan transactions from September 26, 2003, to May 9, 2007, while the other comprises $1,511,874$ observations of loan transactions aggregated to the stock-day level over the period

\footnotetext{
${ }^{3}$ State Street's publicly available white paper, "Lending, Liquidity, and Capital Market-Based Finance," indicates that there were 33 dealers in the equity lending market as of 2001.
} 
September 26, 2003, to December 31, 2007. The database of individual loan transactions includes the number of shares, the daily loan rate, and several identification variables. The loans involve 6,972 unique U.S. equities. The median loan length is 23 days, and the median loan value is $\$ 317,135$.

The loan rate is the interest paid on the borrower's collateral, also known as the rebate rate. The relative scarcity of a particular stock is measured in terms of its specialness, or the difference between its loan rate and the market's prevailing, or benchmark, loan rate. Our data provider computes specialness at the aggregate level, and we use this in reporting the aggregate results (Tables VII and VIII).

To calculate the dispersion in loan fees, we need a loan-specific measure of specialness. However, each lender may have a different benchmark rate. Based on D'Avolio (2002) and Geczy, Musto, and Reed (2002), we take the benchmark rate to be the federal funds rate minus a 10-20 basis point spread for each lender. We use the mode of the distribution of loan fees above the federal funds rate to identify each lender's spread (the difference between the loan rate and the benchmark), by loan size category. ${ }^{4}$ The median spread is 16 basis points, and the spread has a relatively large range: the 25 th percentile is 1 basis point and the 75 th percentile is 50 basis points. Among loans above $\$ 100,000$, the interquartile range is $0-25$ basis points.

\section{B. Lender Relationships}

\footnotetext{
${ }^{4}$ As in D'Avolio (2002) and Geczy, Musto, and Reed (2002), loan-size break points are categorized as small (loans below $\$ 100,000$ ), medium (loans between $\$ 100,000$ and $\$ 1,000,000$ ), and large (loans above $\$ 1,000,000$ ).
} 
We also examine the extent to which lenders have relationships with multiple borrowers. For each stock on each day, we count the number of transactions made by a given lender. Because borrowers consolidate orders to take advantage of volume discounts and thereby minimize transaction costs, each transaction in a given stock on a given day is likely to represent a unique borrower. The number of transactions for each lender, therefore, serves as a proxy for the number of unique borrowers, or "relationships," that a lender has on a given day.

In Table II we report descriptive statistics on the time series of each lender's relationships. Interestingly, we find significant variation across lenders in the mean number of relationships, with the average number of relationships per day ranging between 1.01 and 9.92 . Furthermore, there is a dynamic aspect to the number of relationships: the mean and median are well below the maximum for most firms. To take one example, for lender \#7 the maximum number of relationships is 232 , but the mean number of relationships is only 5.06 , and the median is 2 . Although our notion of searching across lenders is only a qualitative one, the disparity we find between the maximums versus the means and medians is consistent with the view that borrowers search for shares across large numbers of lenders when the shares they seek are scarce. Furthermore, the cross-sectional variation in the number of relationships is consistent with the existence of heterogeneity in search costs.

\section{Data Compilation}

Because we analyze the share loan supply schedule on a stock-by-stock basis, we aggregate daily data on loan fees and quantities to the stock level. To this dataset we add daily 
stock prices and shares outstanding for each firm, using CRSP data for the period 2003-2007. We use Compustat data to calculate daily values for the book-to-market and price-to-earnings ratios.

We winsorize the resulting database at the 1 st and 99th percentiles and filter our database to include only those firms with at least 250 observations. After this filter is applied, 586,435 observations remain in the database. In Table III we report summary statistics for the final sample. The average specialness is highly right-skewed, with a mean value of 0.37 , a standard deviation of 1.36 , and a skewness of 5.86. In addition, the average loan quantity as a percentage of shares outstanding is also highly right-skewed.

\section{Search Frictions, Lender Relationships, and the Number of Small and Large Lenders}

To measure the difficulty of finding lenders for a particular stock, we count the number of lenders that make at least one loan in each stock over the course of the calendar year. We then split the lenders into two groups: large and small. Large lenders are those whose average loan size, for all stocks, is larger than the average for the full sample, while, conversely, small lenders' average loan size is smaller than the average. When the number of small lenders is high for a given stock over the course of a year and the number of large lenders low, the stock likely has higher search frictions, because borrowers are frequently forced to move beyond the large lender base to seek out small lenders, which are presumably more costly to find. 


\section{E. Instruments}

To identify the share loan supply schedule, we must use variables that affect the demand for loans but not the supply. Potential instruments can be found in the extensive literature examining the relation of short selling to various signals that forecast returns. Cao, Dhaliwal, Reed, and Kolasinski (2007) show that short interest is higher after negative earnings surprises and lower after positive ones; Christophe, Ferri, and Angel (2004) find that short selling depends on earnings surprises in general. A number of studies also show that short interest is positively related to discretionary accruals (Cao, Dhaliwal, Reed, and Kolasinski, 2007; Zhang and Cready, 2004; Hirshleifer, Teoh, and Yu, 2006). Accordingly, we consider earnings surprises and discretionary accruals to be two potential instruments for share lending demand.

Dechow, Hutton, Meulbroek, and Sloan (2001) find that various price to fundamental ratios, such as market-to-book and price-to-earnings $(\mathrm{P} / \mathrm{E})$, are related to short interest. Moreover Boehme, Danielson, and Sorescu (2006) find that dispersion in analyst forecasts is positively related to short interest, as suggested by Diether, Malloy, and Scherbina (2002). Finally, since negative momentum tends to forecast negative abnormal returns (Jegadeesh and Titman, 1993), momentum is another possible instrument. Hence, we consider the following variables as possible instruments for short interest: earnings surprises, discretionary accruals, market-to-book ratio, $\mathrm{P} / \mathrm{E}$ ratio, analyst dispersion, and momentum.

We define earnings surprises, market-to-book ratio, and momentum as in Cao, Dhaliwal, Reed, and Kolasinski (2007), and we define discretionary accruals as in Sloan (1996). We calculate $\mathrm{P} / \mathrm{E}$ as the stock price over twelve-month trailing fully diluted earnings per share less 
extraordinary items as of the end of the quarter. (We only include the P/E ratio when earnings per share are positive, since a negative $\mathrm{P} / \mathrm{E}$ ratio is difficult to interpret.) Analyst dispersion is defined as in Diether, Malloy, and Scherbina (2002), and momentum is defined as returns over the prior six-month period. We winsorize each variable at the 1 st and 99th percentile to prevent outliers from influencing our results.

As noted above, to be a valid instrument for our study a variable must be related to share loan demand but unrelated to share loan supply. It is unclear a priori whether any of the proposed instruments meets the latter restriction. To assess the variables in that regard, we determine whether each one affects institutional holdings. Because institutions comprise the majority of share lenders (Fabozzi, 1997), we assume that a variable that does not affect institutional holdings is unlikely to affect share loan supply. We find that neither earnings surprises, nor discretionary accruals, nor analyst forecast dispersion affects institutional holdings, and therefore we consider them valid instruments for the purposes of this study.

\section{Results}

We use two distinct empirical techniques to investigate the role of search costs in the equity lending market. First, we empirically verify that the generic predictions of sequential search cost models hold for the equity loan market - that is, that search costs are positively correlated with price dispersion and the level of prices. We then estimate the share loan supply curve and show that search costs are closely connected to its parameters. 


\section{A. Search frictions in the share loan market}

Duffie, Garleanu, and Pedersen (2002) describe the prevalence of search frictions in the opaque equity lending market. To empirically examine the role that search frictions play, we exploit the unique advantage of our database: its inclusion of multiple lenders. We conduct two sets of tests. First, in section A.1 below we confirm that loan fee dispersion is associated with various proxies for search frictions. This test validates the notion, suggested by the industrial organization search cost literature, that price dispersion is associated with search frictions. We then demonstrate in section A.2 that the loan fee level, or specialness, is a function of dispersion in loan fees in the time series, thereby supporting DGP's assertion that search frictions contribute to the costs of short selling.

\section{A.1. Dispersion and Search Costs}

One of the most relevant empirical predictions of sequential search cost models is that increases in search costs will be associated with increases in price dispersion. To test whether this prediction holds for our data, we first identify appropriate proxies for search costs. Based on DGP's description of the determinants of search costs in the equity lending market, we select market capitalization, liquidity, and ownership concentration as measures of these costs. In addition, we include several variables meant to capture DGP's concept of special activity, including unexpected earnings, divergence of analyst estimates, and discretionary accruals. All 
of these are proxies for an unusually high number of loans, which could lead to increases in search costs. As noted above, we also include variables for the number of small and large lenders active in the lending market for each stock.

For each stock-day we calculate each lender's average specialness. We define CrossLender Dispersion as the standard deviation of average lender specialness across lenders for each stock-day. The results, presented in Table IV, are largely consistent with the prediction that increases in search costs are associated with increases in price dispersion. We find that market capitalization does play a role. The statistically negative coefficient on Size in all three model specifications indicates that larger firms have less price dispersion, which is consistent with D’Avolio (2002) and Geczy, Musto, and Reed (2002), who find that larger firms are more widely held and held in larger quantities by equity lenders, and as a result, their stock is easier to borrow. In other words, loans in large, and presumably widely-held, stocks are associated with lower search costs and lower price dispersion. Further evidence for this is seen in the statistically positive coefficient on another proxy for search costs, Number of Small Lenders. A clear picture emerges: as stocks' scarcity increases, borrowers are forced to search beyond large lenders, and since it can be costly for firms to find smaller lenders, the scarce stocks exhibit increased price dispersion.

Finally, we find a strong effect from liquidity, as suggested by DGP. As a measure of liquidity, we use the bid-ask spread as a percentage of the closing mid-price on that day. We find that the bid-ask spread has a positive and statistically significant effect, implying that lessliquid firms are more likely to be associated with high levels of price dispersion. However, when 
we control for average loan fee and average loan fee squared in models 2 and 3 , respectively, we find that the positive effect of bid-ask spread on price dispersion does indeed disappear. In other words, the fee charged by lenders already accounts for the search costs for illiquid stocks. Overall, this evidence confirms that loan fee dispersion is related to search frictions.

\section{A.2. Specialness and Dispersion}

Building on the search cost literature's prediction that price dispersion is driven by search frictions, which was validated in the previous section, we now investigate whether loan fee levels are related to search frictions. A connection between the level of price dispersion and the cost of borrowing supports the hypothesis that search frictions drive short sale constraints. As a measure of the market-wide loan fee, we use specialness. This measure captures market variation in the difficulty of borrowing shares, and it can potentially alleviate concerns about stock- and lender-specific characteristics of loan pricing.

As in the previous section, we use Cross-Lender Dispersion to measure price dispersion, where Cross-Lender Dispersion is once again calculated as the standard deviation of average loan fees across lenders in a given stock for a given day. The standard deviations for each stockday observation are then organized by market-wide specialness deciles; we report the average of the standard deviations for each decile in Table V. We also compute a measure of dispersion within each lender, specifically, the standard deviation of the lender's loans in each stock for each day. We then take the average of these within-lender standard deviations by market-wide 
specialness category. Another variable, In-Lender Dispersion, captures the extent to which lenders charge different prices to different clients.

Interestingly, for Cross-Lender Dispersion the results are not monotonic: there is a pattern of decreasing dispersion for very low specialness categories and then increasing dispersion as specialness goes from moderate to high (Table V, Panel A). Furthermore, as expected, the level of price dispersion — and therefore search frictions - influences the ability of lenders to charge higher lending fees. These results are statistically significant, as confirmed by the regression results in Panel B that indicate that a $1 \%$ increase in market specialness increases Cross-Lender Dispersion by 0.2066 . The mere fact that lenders have upward-sloping supply schedules when scarcity is high does not, by itself, imply that Cross-Lender Dispersion will be higher in high-scarcity environments. However, the result is consistent with search models, validating the importance of search costs in this opaque market. Taken together, the patterns in price dispersion across lenders in section A.1 and this section provide evidence that costly search contributes to specialness.

The results for In-Lender Dispersion as a function of specialness also are non-monotonic (Table V, Panel A). There is a pattern of decreasing dispersion from low to moderate specialness, and a pattern of increasing dispersion from moderate to high specialness. Regression results support this pattern: market-wide specialness squared is a statistically strong predictor of In-Lender Dispersion. This pattern is consistent with the notion that lenders have monopoly power both when scarcity is high and when it is low, and thus under these conditions lenders are better able to price-discriminate. When scarcity is low, borrowers are not searching 
for securities and thus are not comparing prices, so lenders have more pricing power. On the other hand, when scarcity is high, borrowers face search costs. As the difficulty of finding shares increases, lenders who do make loans have more pricing power. Finally, if mild scarcity drives borrowers to search around for shares but these borrowers can easily find alternatives, the pricing power of the lenders is diminished. Overall, our results constitute strong evidence that specialness is related to search frictions.

\section{B. Modeling the Share Loan Supply Curve}

Presumably, short sale constraints arise as short sellers' demand for share loans increases. ${ }^{5}$ However, not all increases in share loan demand lead to increases in loan fees (Christoffersen, Geczy, Musto, and Reed, 2007). So the question remains, how much must demand increase before loan fees increase?

As a first pass, we conduct a simple experiment, modeled on that of D'Avolio (2002), in which we plot specialness (or excess loan fee) as a function of quantity loaned (Figure 2). To account for persistent differences in loan quantity across securities, we calculate relative quantity loaned. In other words, quantity is measured as the rank of normalized loan quantity, defined as the number of shares lent divided by total shares outstanding. We find that specialness mildly declines in loan quantity at low levels of the latter, but when loan quantity is above the 70th percentile, specialness increases sharply in loan quantity. The changing sensitivity of specialness

\footnotetext{
${ }^{5}$ D'Avolio (2002) shows a positive correlation between short interest and loan fees.
} 
to quantity has practical importance for borrowers: Upward shifts in the quantity demanded do not necessarily increase loan prices and may even decrease them in some cases.

This initial approach is inherently limited, however. The supply schedule cannot be mapped out correctly using prices and quantities unless the supply curve does not shift during the measurement period. To trace out the supply curve more carefully, we turn to a two-stage regression approach, similar to that of Angrist, Graddy, and Imbens (2000). Specifically, we use exogenous shifts in the demand for equity loans as a means to identify the supply curve. As seen in section A, there is good reason to believe that the share loan supply curve may not be linear. To allow for this possibility, we employ a nonlinear technique that builds on the linear approach of Angrist, Graddy, and Imbens.

We test the validity of our instruments for share loan demand in section B.1 below. In section B.2 we describe our technique for estimating the share loan supply curve and present our results. Finally, in section B.3, we examine the relation of the parameters of individual stocks' share loan supply curves to firm-level characteristics.

\section{B.1. Instruments for Share Loan Demand}

In section II we identified several variables from the extant literature that are likely to be related to the demand for share loans. We noted that to be a valid instrument for our study these variables must be unrelated to share loan supply. Since variables that do not affect institutional holdings are very unlikely to affect share loan supply, we look specifically for variables that 
affect short sellers' trading and their demand for share loans, without affecting institutional investors' trading and their supply of share loans.

For each of the stocks in our sample, we obtain quarterly data from Thompson Financial on institutional share holdings from 2002 to 2007 . We take the sum of the shares held by institutions and divide this by total shares outstanding to obtain institutional holdings (insthld) as of the first available report date after the quarterly earnings announcement date. To test whether our instruments affect institutional holdings, we run the following panel data regression:

$$
\begin{aligned}
\text { insthld } & =\alpha+\beta_{1 \text { sue }}+\beta_{2 \text { accruals }}+\beta_{3} P / E+\beta_{4} \text { market-to-book } \\
& +\beta_{5} \text { analyst }+\beta_{6} \text { momentum }+\beta_{7} \log (\text { MktCap })+\varepsilon
\end{aligned}
$$

We include firm fixed effects and use panel-corrected standard errors clustered by firm, making them robust to heteroskedasticity and within-firm serial correlation. As a control, we include the log of a firm's market capitalization as of the fiscal quarter end, $\log (M k t C a p)$, to account for institutional investors' preference for large stocks. Finally, we exclude firm-quarter observations in which earnings per share are negative.

We find that earnings surprises (sue), discretionary accruals (accruals), and analyst dispersion (analyst) do not individually have a statistically significant effect on institutional holdings at even the $10 \%$ level (Table VI). In addition, an F-test fails to reject the null hypothesis that their coefficients are jointly equal to zero. Hence, we conclude that they are related to demand but not supply and therefore are valid instruments. In contrast, the P/E ratio, market-to-book, and momentum are all individually and jointly significant. 
To ensure that our results for earnings surprises, discretionary accruals, and analyst dispersion do not change when we add observations with negative earnings per share, we re-run the above model on a broader sample of data, excluding only the P/E ratio as an explanatory variable. As before, the coefficients on earnings surprises, discretionary accruals, and analyst dispersion are all individually and jointly statistically indistinguishable from zero. Based on this evidence, we choose earnings surprises, discretionary accruals, and analyst dispersion as instruments.

\section{B.2. Estimating the Share Loan Supply Schedule}

Using these valid instruments, we estimate the share loan supply curve, which allows us to determine the influence of short sellers' demand for share loans on the price of loans and the extent to which increases in loan prices are related to search frictions. We estimate a supply schedule separately for each stock because this allows us to study the relation of the parameters of the schedule to individual firm characteristics. While this disaggregated approach could be costly in terms of the precision of the supply curve coefficient estimates, the richness of the database permits such an approach. The quantity and specialness variables used in the study are aggregate statistics reflecting the input of twelve different lenders, and this diversity reduces the need for pooling, since a primary motivation for the formation of portfolios in the context of daily stock prices is to reduce the noisiness of individual stock estimates.

To conduct cross-sectional comparisons of supply curves, we must ensure that our supply curve parameters are comparable across stocks. We therefore standardize each stock's quantity 
by first dividing each stock's quantity of loans by shares outstanding. This removes the effect of stock price on quantity, which would likely be sufficient for an estimation using market-wide quantity. However, since our lenders hold only a segment of the lendable supply of each stock, and since that segment may vary by stock, we need to further normalize each stock's quantity. Thus, we standardize each stock's quantity variable by subtracting the mean and dividing by the standard deviation of each stock's loan quantity as a percentage of shares outstanding. We label this standardized value of share loan quantity $Q$. Standardizing quantity also allows us to make meaningful comparisons of our stock-specific supply curve parameter estimates.

Because the quantity of shares lent and the lending fee are equilibrium values that result from the interaction of supply and demand, we must use a simultaneous-equations approach to estimate the share loan supply schedule, that is, the relation between the quantity supplied and the lending fee. To identify the supply schedule, we need instruments for quantity demanded, specifically, variables that affect demand but not supply. We have already identified several such instruments, including earnings surprises (sue), discretionary accruals (accruals), and dispersion in analyst forecasts (analyst). The use of accounting variables as instruments presents a challenge: $Q$ has a daily frequency, whereas the frequency of earnings surprises and discretionary accruals is quarterly. However, because the abnormal returns that normally follow earnings surprises (Bernard and Thomas, 1990) and high discretionary accruals (Sloan, 1996) persist for at least 120 days, we can assume that these variables continue to affect share loan demand on a daily basis for up to 120 days after an earnings announcement. 
Having identified a set of instruments, we can represent the share loan demand and supply schedules as the following limited information system, with the supply schedule (3) as the identified equation:

$$
\begin{aligned}
& Q=\gamma_{0}+\gamma_{1} F+\gamma_{2} \text { sue }+\gamma_{3} \text { accruals }+\gamma_{4} \text { analyst }+\gamma_{5} \text { fedfunds }+\eta \\
& F=\alpha+\beta_{1} Q+\beta_{2} Q^{2}+\beta_{3} \text { fedfunds }+\varepsilon
\end{aligned}
$$

where $Q$ is loan quantity and $F$ is the lending fee. We estimate equation (3) for each stock using the nonlinear least squares procedure suggested by Wooldridge (2002). ${ }^{6}$ We then aggregate our results to obtain a market-wide interpretation of parameter estimates by calculating the crosssectional means and medians of the coefficient estimates for the combined sample of stocks (Table VII).

Consistent with a U-shaped supply curve (Figure 3), both the mean and median coefficient estimates on the quadratic term are positive. For most of the sample, shifts in demand are associated with only a small change in price. For example, an increase in standardized loan quantity from the 25 th percentile to the 75 th percentile is associated with a price change of only $0.0320 \%$ (an increase from $0.2111 \%$ to $0.2431 \%$ ). However, at high quantity values, a onestandard-deviation increase in demand increases abnormal loan fees from $1.83 \%$ to $5.55 \%$. This finding helps reconcile seemingly conflicting findings in the literature, which has shown shifts in demand to have both small and large effects on price. Since quantity is standardized, the mean parameter estimates imply that the average firm's supply curve slopes downward until quantity reaches a point that is 0.2297 standard deviations below the mean $[-0.2297=-0.4942$ /

\footnotetext{
${ }^{6}$ We stress that we are not running what Wooldridge calls "the forbidden regression," but rather the more involved, unbiased procedure he describes (2002: 236-237).
} 
$(2 * 1.0755)]$. Assuming a federal funds rate of $2 \%$ and substituting the mean parameter estimates into equation (3), we see that the expected specialness at this minimum point equals $0.20 \%{ }^{7}$

Simple $t$-tests of the means of the coefficient estimates generally fail to reject the null hypothesis that they equal zero. The mean of the quadratic term coefficient is significant, but only at the $10 \%$ level. This lack of strong statistical significance may at first glance cast doubt upon our central hypotheses. However, the lack of statistical significance of coefficient estimate means can have several interpretations. It may be the case that the coefficient estimates are tightly clustered and centered around zero; this interpretation would in fact cast doubt on our hypotheses. Alternatively, each stock may have significant coefficient estimates that vary widely from stock to stock, so the cross-sectional distribution identifies no statistical pattern. Finally, the distribution of coefficient estimates may in fact be centered significantly above (or below) zero, but skewness, kurtosis, or other deviation from the normal distribution causes the $t$-test to have lower power.

To allow stocks to have widely different parameter estimates and still determine whether slopes are, on average, statistically important, we estimate the $p$-values of the parameters for each stock and examine the cross-sectional distribution of these $p$-values. Specifically, we conduct a Fisher test of combined probability, also known as the chi-square test, to determine whether the cross-sectional distribution of the $p$-values differs significantly from a uniform zeroone distribution. Under the null hypothesis that specialness is generally invariant to quantity demanded and a low $p$-value estimate for any stock is due simply to chance, we expect $p$-values

\footnotetext{
${ }^{7}$ Due to the highly right-skewed distribution of standardized loan quantity, the mean is well above the median. The mean of standardized loan quantity is zero, which falls in the 77th percentile of the distribution (Figure 3).
} 
to be uniformly distributed between zero and one. We reject the null at the $1 \%$ level of significance for all parameter estimates. In other words, although the parameters of the supply curve vary widely from stock to stock, they tend to be statistically different from zero in the cross-section. This provides evidence that quantity demanded does have statistically important linear and nonlinear effects on specialness.

To determine whether the distribution of the quadratic term coefficient estimates is centered above zero, we conduct a nonparametric Wilcoxon signed-rank test, which unlike the $t$ test makes no assumptions about normality. We reject the null hypothesis that the coefficient estimates are centered around zero at the $1 \%$ significance level. Together with our finding that the mean and median of the quadratic term coefficient estimates are positive, this constitutes strong evidence that quadratic terms tend to be positive in the cross-section, which in turn implies that the share loan supply curve tends to be U-shaped, as hypothesized.

In addition to the quadratic specification discussed above, we examine several other possible specifications for the loan supply schedule, including piecewise linear models with one structural break and with two structural breaks. The results for the models are not qualitatively different, and they support the existence of the U-shaped supply curve discussed above.

\section{B.3. Cross-Sectional Patterns in Supply Curves}

Given the supply curve parameter estimates, we further test the importance of search costs in the equity lending market by examining the relation between the supply curve 
parameters and various firm characteristics. Specifically, we run the following cross-sectional regressions for each coefficient estimate:

$$
\begin{aligned}
\text { estimate }= & \alpha+\beta_{1}(\log (\text { MktCap }))+\beta_{2}(\text { bid-ask spread })+\beta_{3}(\text { Number of Small Lenders }) \\
& +\beta_{4}(\text { Number of Large Lenders })+\beta_{5}(\text { analyst })+\beta_{6}(\text { insthld })+\varepsilon
\end{aligned}
$$

where the dependent variables are the stock-specific parameter estimates from equation (3), estimated in the previous section The stock is the unit of observation for these regressions. The independent variables are defined as follows: $\log ($ MktCap $)$ is the log of market capitalization; bid-ask spread is the bid-ask spread measured as a percentage of the closing mid-price; Number of Small Lenders and Number of Large Lenders are the number of small and large lenders in the stock as defined in section II; analyst is the dispersion in analyst estimates as defined in section II; and insthld is the percentage of shares held by institutions. We run the regressions on the full sample of firms as well as on three subsamples (small, medium, and large firms).

The results, shown in Table VIII, further support the importance of search costs in the equity lending market. The first row of Panel A shows the relation of the constant term of the supply curve estimates to the firm characteristics discussed above. The coefficient on the log of the market capitalization is negative and statistically significant, indicating that large firms tend to have lower specialness. Since DGP assert that larger size is associated with lower search costs, our results support the hypothesis that increased search costs lead to higher specialness. The number of small lenders is also positively and significantly associated with a higher constant term. A similar result holds for the subsample of small firms (Panel B). Because the number of small lenders in a stock is likely to be correlated with search costs (see section II above), this 
finding also supports the hypothesis that greater search costs lead to higher average specialness. Moreover, the number of large lenders is negatively associated with search costs, although the effect is only statistically significant for the subsample of large firms (Panel D). Interestingly, increased bid-ask spreads are generally related to a lower constant term, which runs contrary to the search costs hypothesis. However, the effect appears to be attributable to the sample of small firms (Panel B) ${ }^{8}$

For the full sample, firm characteristics do not generally have a significant effect on either the linear or quadratic quantity parameters of the supply curve. The two exceptions are the number of small lenders and institutional holdings. The number of small lenders makes specialness more sensitive to quantity demanded in the linear term. This result supports the idea that stocks lent more frequently by small lenders have higher search costs, so lenders take advantage of their increased pricing power in these stocks. Similarly, institutional holdings makes specialness less sensitive to quantity demanded in the quadratic term, which supports the view that lenders have less pricing power in stocks that are widely held by institutions and, presumably, by lenders.

\section{Conclusion}

In this study we have explored the role of search costs in the equity lending market. Drawing on Duffie, Garleanu, and Pedersen (2002), we relate search costs, average price levels,

\footnotetext{
${ }^{8}$ As a robustness check, we verified that our results are not sensitive to controlling for a dummy variable that takes the value 1 if a firm participated in the Regulation SHO pilot program and 0 otherwise (results available upon request). See http://www.sec.gov/spotlight/shopilot.htm or Diether, Lee, and Werner (2007) for more information.
} 
and price dispersion and in so doing confirm that search plays an important role in the equity lending market. Specifically, we document a positive relation between price dispersion in lending fees, the average level of fees, and proxies for search costs. We also show that the share loan supply schedule is non-monotonic: it slopes downward when quantity is low and upward when quantity, and search costs, are high. Most of the time, however, it is relatively flat, reflecting the very low sensitivity of specialness to quantity. We further reinforce the importance of search costs by demonstrating that the parameters of individual stocks' share loan supply schedules are related to firm characteristics that proxy for search costs.

Knowledge about patterns in lending fees has important and practical implications for investors. Based on our findings, short sellers will be able to more accurately predict fees for trades they are considering and better evaluate the competitiveness of fees they have paid in the past. Furthermore, principal owners will be able to predict the revenue to be generated from various equity lenders when considering an equity lending strategy. Similarly, these owners will be able to better evaluate the performance of existing lending programs.

Regulators have recently been interested in removing barriers to short selling in an attempt to increase market quality. ${ }^{9}$ Our research suggests that search costs in the equity lending market represent significant barriers to short sellers and that, at least theoretically, a reduction in the barriers would be straightforward. Search costs could be reduced, or possibly eliminated, by the creation of a central reporting mechanism for share availability and loan pricing, such as the

\footnotetext{
${ }^{9}$ The Security and Exchange Commission's Regulation SHO prohibited the use of price tests for short selling after December 2006 (SEC, 2007).
} 
NYSE lending post that was eliminated in the 1930 s. $^{10}$ To date, the equity loan market remains relatively opaque despite the increasing accessibility of electronic networks.

Finally, in this paper we demonstrate that, as a whole, lenders do indeed benefit from an opaque equity lending market. Difficulty in finding shares gives lenders the ability to set different prices, and to set higher prices. This is, in effect, one reason that the large and important equity loan market is opaque: lenders benefit—sometimes significantly—from search costs.

${ }^{10}$ According to the search cost literature, the welfare effects of a central clearing house are highly dependent on institutional details (see, e.g., Rosenthal, 1980; Varian, 1980; and Baye and Morgan, 2001). 


\section{REFERENCES}

Angrist, J., K. Graddy and G. Imbens, 2000. "The Interpretation of Instrumental Variables Estimators in Simultaneous Equations Models with an Application to the Demand for Fish," The Review of Economic Studies, 67(3), 499-527.

Asquith, P., P. Pathak and J. Ritter, 2005, "Short Interest, Institutional Ownership, and Stock Returns," Journal of Financial Economics, 78, 243-276.

Baye, M., John Morgan and Patrick Scholten. 2006. "Information, Search, and Price Dispersion." Forthcoming in Handbook on Economics and Information Systems (Elsevier, T. Hendershott, ed.)

Bernard, V., and J. Thomas, 1990. "Evidence That Stock Prices Do Not Fully Reflect the Implications of Current Earnings for Future Earnings," The Journal of Accounting and Economics, 13, 305-340.

Boehme, R., B. Danielsen, and S. Sorescu, 2006, "Short Sale Constraints, Short-sale constraints, dispersion of opinion and overvaluation," Journal of Financial and Quantitative Analysis, 41(2), 455-487.

Boehmer, E., C. Jones and X. Zhang, 2008, "Shackling the Short Sellers: The 2008 Shorting Ban", Texas A\&M Working Paper.

Cao, B., D. Dhaliwal, A. Kolasinski and A. Reed, 2007. "Bears and Numbers: Investigating How Short Sellers Exploit and Affect Earnings-Based Pricing Anomalies." University of Washington Working Paper.

Christoffersen, S., C. Geczy, D. Musto and A. Reed, 2007, "Vote Trading and Information Aggregation," Journal of Finance, 62(6), 2897 - 2929.

Christophe, S., M. Ferri, and J. Angel, 2004, "Short-Selling Prior to Earnings Announcements," Journal of Finance, 59, 1845-1875.

Cohen, L., K. Diether, and C. Malloy, 2007, "Supply and Demand Shifts in the Shorting Market," Journal of Finance, 62(5), 2061-2096.

D’Avolio, Gene, 2002, “The market for borrowing stock," Journal of Financial Economics, 66, 271-306.

Dechow, P., A. Hutton, L. Meulbroek, R. Sloan, 2001, “Short Interest, Fundamental Analysis and Market Efficiency," Journal of Financial Economics, 61, 77-106. 
Diamond, D., and R. Verrecchia, 1987, "Constraints on short-selling and asset price adjustment to private information," Journal of Financial Economics, 18, 277-311.

Diether, K., K. Lee, and I. Werner, 2007, "It's SHO Time! Short-sale Price Tests and Market Quality," 2007, Journal of Finance, forthcoming.

Diether, K., C. Malloy, and A. Scherbina, 2002, "Differences of Opinion and the Cross-Section of Stock Returns," Journal of Finance, 57, 2113-2141.

Duffie, D., N. Garleanu, and L. Pedersen, 2002, "Securities Lending, Shorting, and Pricing," Journal of Financial Economics, 66, 307-339.

Duffie, D., N. Garleanu, and L. Pedersen, 2006, " Valuation in Over-the-Counter Markets," Stanford University Working Paper.

Fama, Eugene D., and James D. MacBeth, 1973, "Risk, Return, and Equilibrium: Empirical Tests", The Journal of Political Economy, 81, 607-636.

Fabozzi, F., 1997, Securities Lending and Repurchase Agreements, Frank J. Fabozzi Associates, New Hope Pennsylvania.

Geczy, C., D. Musto, and A. Reed, 2002, "Stocks are Special Too: An Analysis of the Equity Lending Market," Journal of Financial Economics, 66, 241-269.

Hirshleifer, D., S. Teoh, and J. Yu, 2007, "Do short-sellers arbitrage accrual-based return anomalies? Working Paper.

Hong, H., and J. Stein, 1999, "A Unified Theory of Underreaction, Momentum Trading and Overreaction in Asset Markets," Journal of Finance, 54, 2143-2184.

Titman, S. and N. Jegadeesh, 1993, "Returns to Buying Winners and Selling Losers: Implications for Stock Market Efficiency,” Journal of Finance, 48(1), 65-91.

Miller, E., 1977, “Risk, Uncertainty, and Divergence of Opinion,” Journal of Finance, 32, 11511168.

Ofek, E. and M. Richardson, 2003, "DotCom Mania: The Rise and Fall of Internet Stock Prices," Journal of Finance, 58, 1113-1138.

Reinganum, J.F., 1979. “A Simple Model of Equilibrium Price Dispersion.” Journal of Political Economy, 87, 851-858.

Reed, Adam V. 2007, Costly Short-Selling and Stock Price Reactions to Earnings Announcements, Working Paper, University of North Carolina. 
Securities and Exchange Commission, 2007, "Regulation SHO and Rule 10a-1", Release No. 3455970, File No. S7-21-06.

Sloan, R. G., 1996. "Do Stock Prices Fully Reflect Information in Accruals and Cash Flows about Future Earnings?” Accounting Review, 71, 289-315.

Sirri, Erik R., and Peter Tufano, 1998, "Costly search and mutual fund flows," Journal of Finance 53, 1589-1622.

State Street Corporation, 2001, "Securities Lending, Liquidity, and Capital Market-Based Finance," white paper.

Wooldridge, J. Econometric Analysis of Cross Section and Panel Data. MIT Press, 2002, pp. 236-237.

Zhang, Y. and W. Cready., 2004, "Do Speculative Short Sellers Detect Earnings Management?" Papers and Proceedings of the American Accounting Association Meetings. 


\section{Figure 1}

\section{Structure of Equity Lending Market}

Figure 1 indicates how hedge funds HF1 through HFN1 can be clients of multiple prime brokers PB1 through PBN2. These prime brokers have relationships with multiple securities lenders L1 through LN3. The relationships with lenders can be thought of as regular (bold line), occasional (solid line), or infrequent (dashed line).

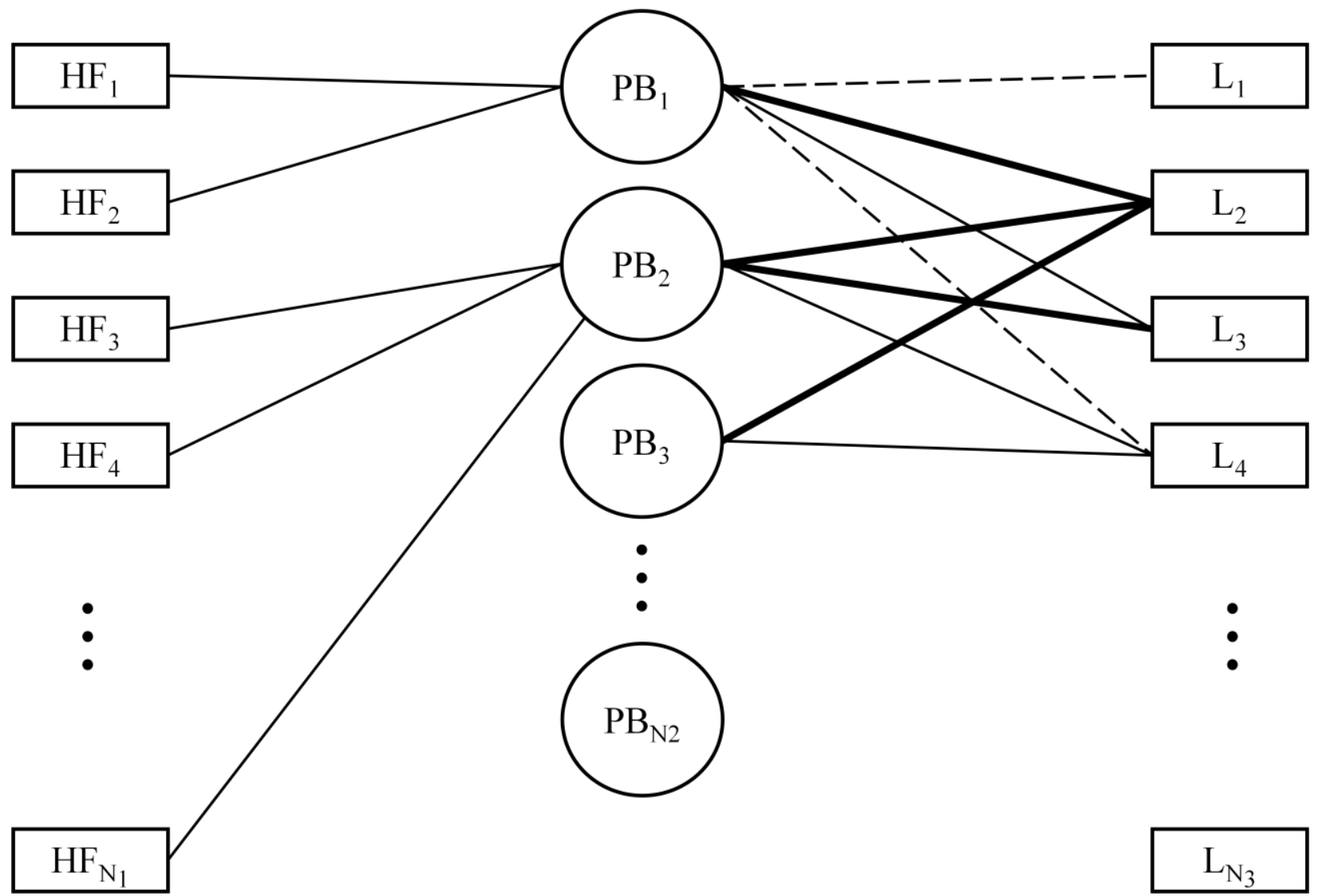


Figure 2

Specialness as a Function of Trade Quantity in 2006

Trade quantity is divided by Outstanding Shares in order to account for persistent differences in loan quantities across securities. For each firm, these relative quantities are then assigned to a decile based on their position relative to other trade quantities for that firm and year. The figure plots the average specialness across all firms for each decile. Specialness, in percent, is calculated by first identifying the prevailing rate and then subtracting this benchmark from each loan's rate.

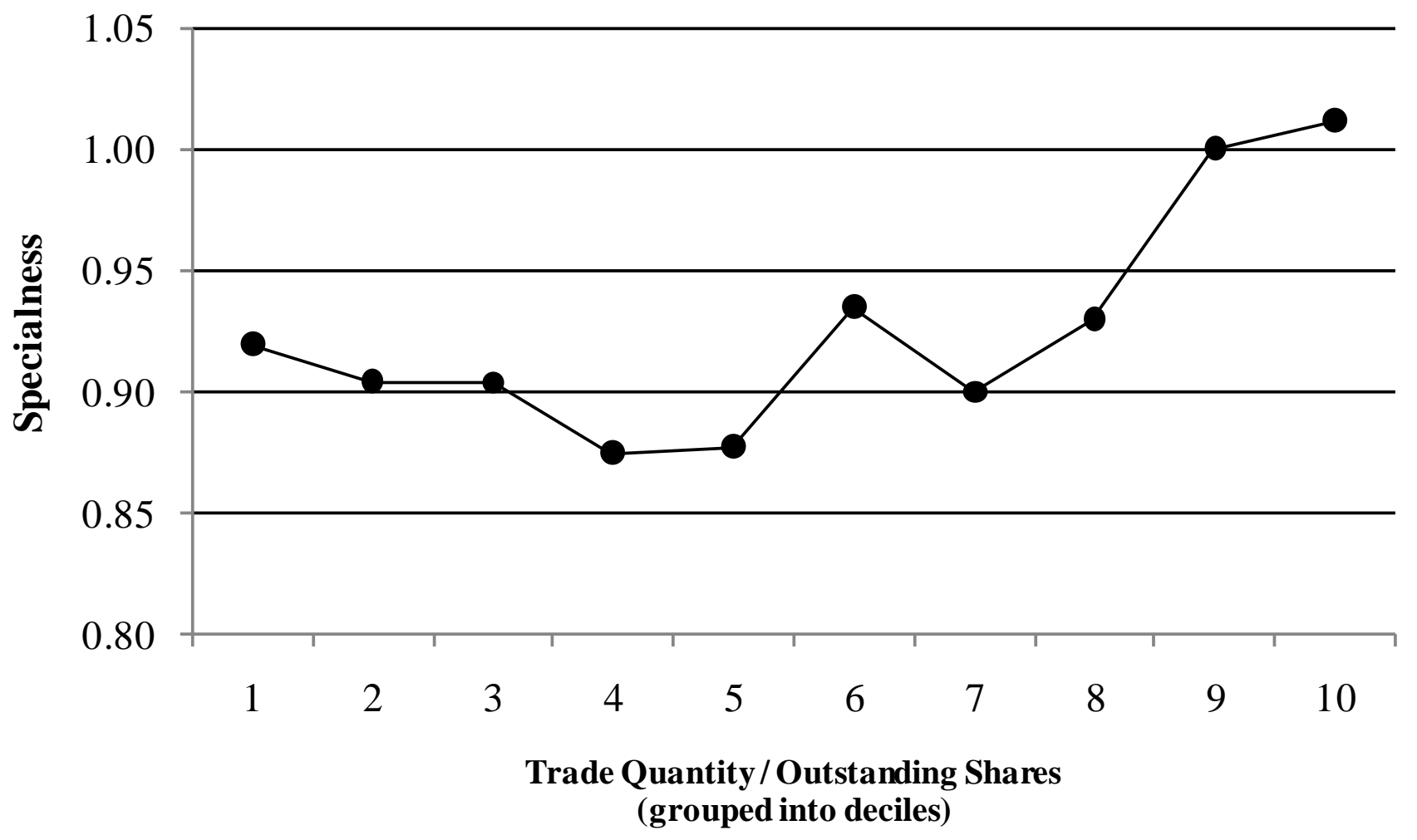


Figure 3

The Share Loan Supply Curve for the Average Stock

Loan quantity is divided by the number of shares outstanding, and then demeaned and normalized by standard deviation in order to account for persistent differences in loan quantities across securities. Specialness, in percent, is calculated by first identifying the prevailing rate and then subtracting this benchmark from each loan's rate. The supply curve is then estimated for each stock using a non-linear two-stage least squares approach. Details of the supply curve estimation technique are presented in Section III.B of the text. The figure is constructed from the cross-sectional means of these estimates (shown in Table VII). The dashed lines represent the $25^{\text {th }}$ and $75^{\text {th }}$ percentiles of standardized quantity, and the figure is plotted between the $10^{\text {th }}$ and the $90^{\text {th }}$ percentile.

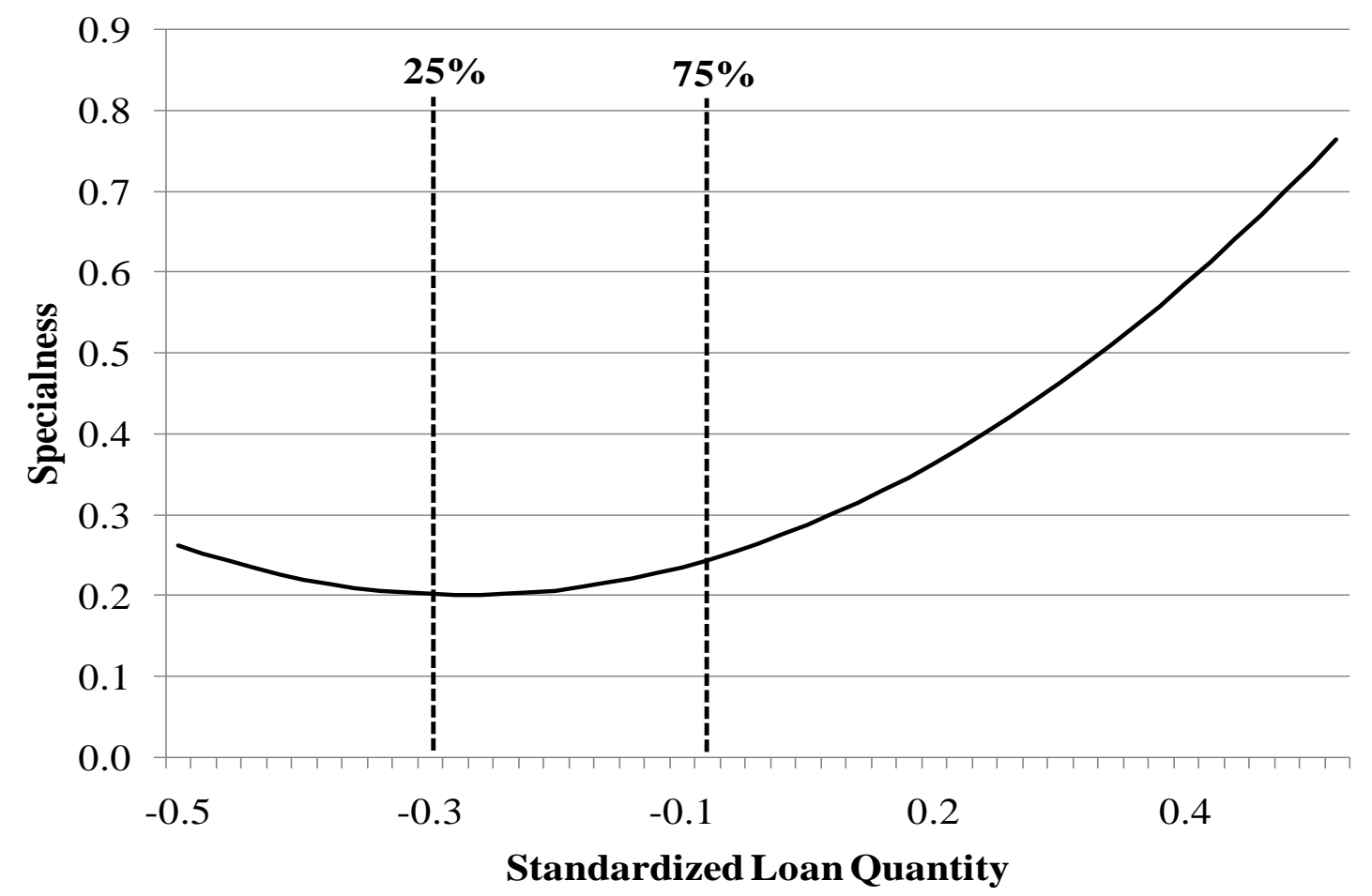




\section{Table I}

\section{Equity Lending Database Statistics}

Table I presents summary statistics for the equity lending database. The database covers September $26^{\text {th }}, 2003$ through May $9^{\text {th }}, 2007$ (for certain lenders the coverage is a subset of this time period). Number of Loans is the average number of loans made in each stock on a daily basis. Rebate Rate is the rebate rate on cash collateral for securities on loan. The database is discussed in detail in Section II of the text.

\begin{tabular}{|c|c|c|c|c|c|c|}
\hline \multirow[b]{2}{*}{ Firm ID } & \multirow[b]{2}{*}{ Lender Type } & \multirow[b]{2}{*}{ Description } & \multicolumn{2}{|c|}{$\begin{array}{l}\text { Number of Loans } \\
\text { (stock / day) }\end{array}$} & \multicolumn{2}{|c|}{$\begin{array}{c}\text { Rebate Rate } \\
\text { (in percent) }\end{array}$} \\
\hline & & & Mean & Median & Mean & Median \\
\hline 1 & Broker Dealer & Broker Dealers box to other broker dealer, some lending to hedge funds & 2.85 & 1.00 & 1.63 & 1.55 \\
\hline 2 & Broker Dealer & Retail Brokerage Accounts lent to broker-dealers & 1.28 & 1.00 & 2.65 & 1.50 \\
\hline 3 & Broker Dealer & Broker Dealer box to other broker-dealers, conduit trades & 2.02 & 1.00 & 4.13 & 4.25 \\
\hline 4 & Direct Lender & Hedge fund assets lent directly to broker dealers & 9.92 & 8.00 & 0.78 & 1.08 \\
\hline 5 & Broker Dealer & Broker Dealers box to other broker-dealers, conduit trades & 1.25 & 1.00 & 2.47 & 2.00 \\
\hline 6 & Broker Dealer & Broker Dealers box to other broker dealer, some lending to hedge funds & 5.74 & 4.00 & 4.20 & 4.30 \\
\hline 7 & Broker Dealer & Broker Dealers box to other broker dealer, some lending to hedge funds & 5.07 & 2.00 & 2.53 & 1.75 \\
\hline 8 & Direct Lender & Mutual Fund assets direct to broker-dealers & 1.87 & 1.00 & 3.19 & 3.15 \\
\hline 9 & Broker Dealer & $\begin{array}{l}\text { Hedge Fund, Pension Plans assets lent directly to other hedge funds or broker } \\
\text { dealers, some conduit trades }\end{array}$ & 3.27 & 2.00 & 4.60 & 5.15 \\
\hline 10 & Direct Lender & Hedge Fund assets lent directly to broker dealers. & 1.01 & 1.00 & 2.58 & 1.00 \\
\hline 11 & Agent Lender & Endowments, Pension Plan assets lent to broker-dealers & 1.43 & 1.00 & 4.33 & 4.75 \\
\hline 12 & Agent Lender & Institutional assets lent to broker dealers & 2.42 & 1.00 & 2.27 & 1.02 \\
\hline
\end{tabular}




\section{Table II}

\section{Number of Relationships by Lender}

Table II provides summary statistics detailing the average number of loan transactions that were completed for each stock on a given day by a given lender. Specifically, for each lender the number of relationships is calculated by first counting the number of transactions that the lender participates in for each stock in the database on a particular day (e.g., lending firm 1 lends shares of firm A on four separate occasions on July $1^{\text {st }}$ ). Then, this number is averaged across all stocks and then across all dates to give the number of relationships for that lender.

\begin{tabular}{|c|c|c|c|c|}
\hline \multirow[b]{2}{*}{$\begin{array}{l}\text { Lending } \\
\text { Firm ID } \\
\end{array}$} & \multirow[b]{2}{*}{$\begin{array}{c}\text { Percent of } \\
\text { Observations }\end{array}$} & \multicolumn{3}{|c|}{ Number of Relationships } \\
\hline & & Mean & Median & Maximum \\
\hline 1 & $16.10 \%$ & 2.84 & 1 & 225 \\
\hline 2 & $7.86 \%$ & 1.27 & 1 & 26 \\
\hline 3 & $6.85 \%$ & 2.02 & 1 & 31 \\
\hline 4 & $0.07 \%$ & 9.92 & 8 & 204 \\
\hline 5 & $3.52 \%$ & 1.25 & 1 & 39 \\
\hline 6 & $31.39 \%$ & 5.74 & 4 & 136 \\
\hline 7 & $6.63 \%$ & 5.06 & 2 & 232 \\
\hline 8 & $17.92 \%$ & 1.87 & 1 & 102 \\
\hline 9 & $0.83 \%$ & 3.27 & 2 & 40 \\
\hline 10 & $0.30 \%$ & 1.01 & 1 & 2 \\
\hline 11 & $4.95 \%$ & 1.43 & 1 & 101 \\
\hline 12 & $3.58 \%$ & 2.41 & 1 & 75 \\
\hline
\end{tabular}




\section{Table III}

\section{Summary Statistics of Instruments and Short Sale Variables}

Table III contains summary statistics for the short sale transaction variables and the instrument variables used in the two-stage regression analyses for the period September $26^{\text {th }}, 2003$ through May $9^{\text {th }}, 2007$. The short sale transaction variables are filtered to include only those firms with at least 250 observations in the database. Market Capitalization, in billions, is computed using data from CRSP. The Federal Funds Rate is the effective rate available in the H.15 statistical release from the Federal Reserve. The construction of the instruments is discussed in detail in Section II of the text.

\begin{tabular}{lccccc}
\hline Variable & N & Mean & Median & $\begin{array}{c}\text { Standard } \\
\text { Deviation }\end{array}$ & Skewness \\
\hline Market Capitalization (\$ Billions) & 578,018 & $12.5 \mathrm{~B}$ & $3.5 \mathrm{~B}$ & $30.8 \mathrm{~B}$ & 6.5445 \\
Federal Funds Rate (in percent) & 1,322 & 3.2189 & 3.2700 & 1.6580 & -0.0889 \\
& & & & & \\
Instruments & & & & & \\
\hline Discretionary Accruals & 8,925 & 0.0608 & 0.0041 & 0.8491 & 20.0765 \\
Dispersion of Analyst Estimates & 8,838 & 0.1002 & 0.0271 & 0.6326 & 35.4391 \\
Earnings Surprise & 8,925 & -0.0106 & -0.0186 & 1.0372 & -0.0429 \\
& & & & & \\
Short Sale Transactions & & & & & \\
\hline Aggregate Specialness (in percent) & 586,435 & 0.3736 & 0.0420 & 1.3665 & 5.8600 \\
\begin{tabular}{l} 
Loan Quantity / Outstanding Shares \\
\hline \hline
\end{tabular} & 578,022 & $0.0494 \%$ & $0.0112 \%$ & $0.1611 \%$ & 7.5424 \\
\hline
\end{tabular}




\section{Table IV}

\section{Determinants of Price Dispersion}

Table IV examines the relation between the standard deviation of the loan fee (specialness) and various firm characteristics. $\log (\mathrm{MktCap})$ is the log of market capitalization from CRSP. The Number of Small (Large) Lenders variable represents the mean number of small (large) lenders who dealt in a particular stock over the entire sample period. Earnings Surprise, Dispersion of Analyst Estimates, and Discretionary Accruals are discussed in Section II.D of the text. Bid-Ask Spread is measured as a percentage of the closing mid-price on each day. All data is weekly; to obtain data at a weekly frequency, the variables are calculated as the time-series mean of daily observations. T-statistics are below the reported parameter estimates in italics and were calculated using standard errors clustered at the firm level with weekly fixed effects. $* * *$ indicates significance at the $1 \%$ level, $* *$ indicates significance at the $5 \%$ level, and * indicates significant at the $10 \%$ level.

\begin{tabular}{|c|c|c|c|}
\hline \multirow[b]{2}{*}{ Explanatory Variable } & \multicolumn{3}{|c|}{ Model } \\
\hline & (1) & (2) & (3) \\
\hline Intercept & $\begin{array}{c}1.2187 * * * \\
(9.13)\end{array}$ & $\begin{array}{c}0.5627 * * * \\
(7.96)\end{array}$ & $\begin{array}{c}0.4406 * * * \\
(6.03)\end{array}$ \\
\hline Log(MktCap) & $\begin{array}{c}-0.0745 * * * \\
\quad(-9.57)\end{array}$ & $\begin{array}{c}-0.0318 * * * \\
(-7.47)\end{array}$ & $\begin{array}{c}-0.0231 * * * \\
(-5.47)\end{array}$ \\
\hline Number of Small Lenders & $\begin{array}{c}0.2499 * * * \\
(8.34)\end{array}$ & $\begin{array}{c}0.1116^{* * * *} \\
(7.37)\end{array}$ & $\begin{array}{c}0.0854 * * * \\
(6.59)\end{array}$ \\
\hline Number of Large Lenders & $\begin{array}{l}0.0187 \\
(1.19)\end{array}$ & $\begin{array}{c}0.0231 * * * \\
(2.69)\end{array}$ & $\begin{array}{c}0.0187 * * \\
(2.00)\end{array}$ \\
\hline Discretionary Accruals & $\begin{array}{c}0.0073 \\
(0.86)\end{array}$ & $\begin{array}{c}-0.0031 \\
(-0.47)\end{array}$ & $\begin{array}{l}-0.0070 \\
(-0.91)\end{array}$ \\
\hline Dispersion of Analyst Estimates & $\begin{array}{l}0.0058 \\
(1.53)\end{array}$ & $\begin{array}{c}0.0006 \\
(0.17)\end{array}$ & $\begin{array}{l}-0.0022 \\
(-0.51)\end{array}$ \\
\hline Earnings Surprise & $\begin{array}{c}-0.0034 \\
(-0.79)\end{array}$ & $\begin{array}{c}-0.0001 \\
(-0.04)\end{array}$ & $\begin{array}{r}-0.0007 \\
(-0.24)\end{array}$ \\
\hline Bid - Ask Spread & $\begin{array}{c}35.8493 * * * \\
(3.56)\end{array}$ & $\begin{array}{l}2.7381 \\
(0.56)\end{array}$ & $\begin{array}{l}-4.2390 \\
(-0.87)\end{array}$ \\
\hline Mean Loan Fee & & $\begin{array}{c}0.1694 * * * \\
(9.18)\end{array}$ & $\begin{array}{c}0.2562 * * * \\
(8.51)\end{array}$ \\
\hline Mean Loan Fee Squared & & & $\begin{array}{c}-0.0055^{* * *} \\
(-3.41)\end{array}$ \\
\hline $\mathrm{N}$ & 81,563 & 81,563 & 81,563 \\
\hline
\end{tabular}




\section{Table V \\ Price Dispersion}

Variations in lending fees (specialness) are calculated as the standard deviation of each lender's price for a given security and day. Cross Lender Dispersion is the average standard deviation of lender's average prices. Specifically, for each stock and day we calculate each lender's average specialness and take the standard deviation of the sample of lenders' averages. The standard deviations are then organized by market-wide specialness deciles and averaged. In Lender Dispersion is the standard deviation of a particular lender's loans in each stock every day and we take the average of these in lender standard deviations by specialness deciles. Panel A shows a graph of cross lender and in lender price dispersion as a function of scarcity, while Panel B shows the Fama and MacBeth (1973) style regression results from models of price dispersion on market wide specialness. Each regression is on a firm by firm basis, and Fama and MacBeth (1973) style T-statistics are below the parameter estimates in italics. $* *$ indicates significance at the $1 \%$ level, and $*$ indicates significance at the $5 \%$ level.

Panel A: Price Dispersion

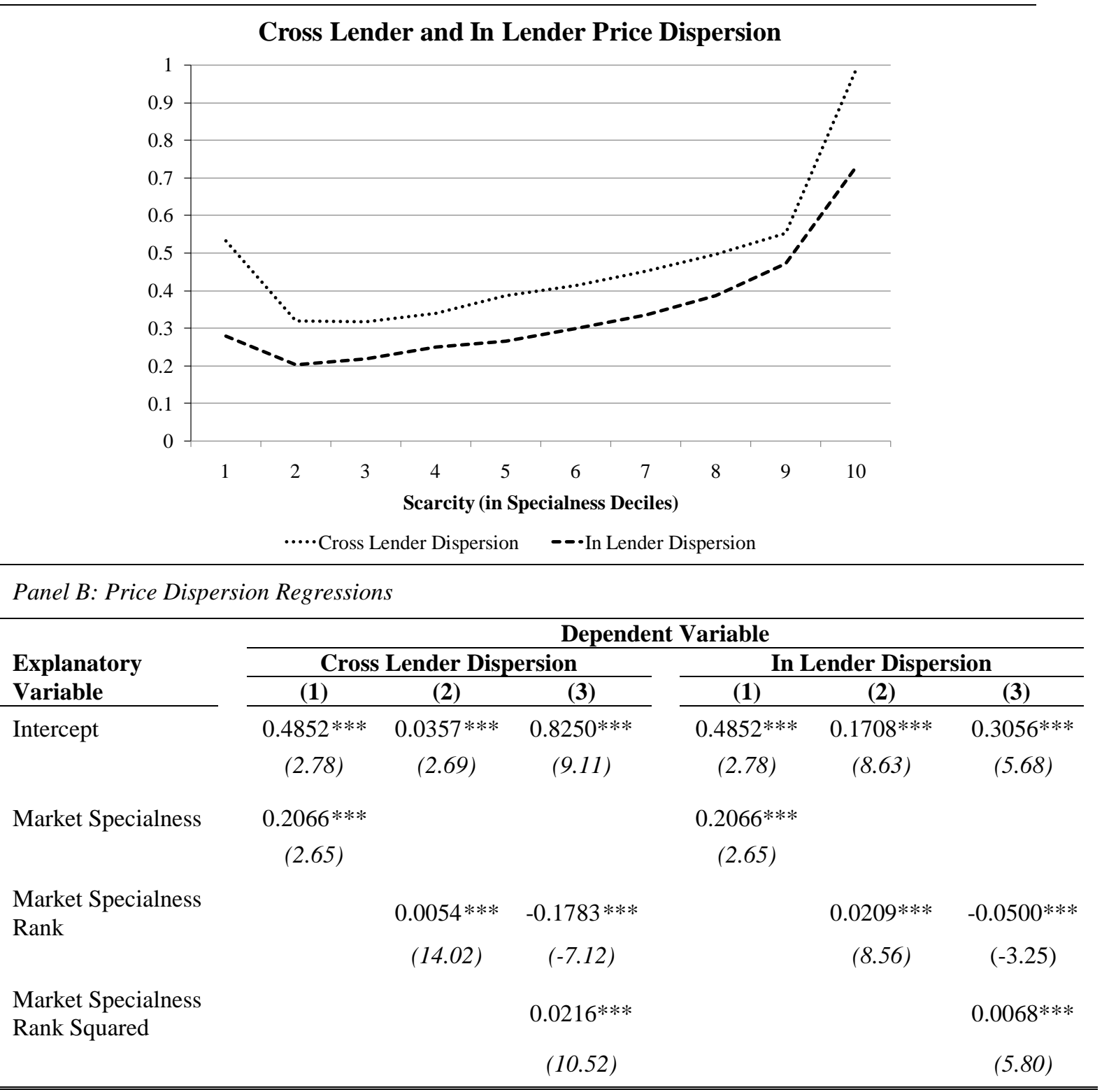


Table VI

Effect of Candidate Instrumental Variables on Institutional Ownership

Table VI displays the results of a panel data regression of quarterly institutional holdings (as a percentage of shares outstanding) on various candidate instruments for the period 2002-2008. Variables are defined in Section III.B of the text. T-statistics are below the reported parameter estimates in italics and were calculated using panelcorrected standard errors clustered at the firm level with firm fixed effects. indicates significance at the $1 \%$ level, $* *$ indicates significance at the $5 \%$ level, and $*$ indicates significant at the $10 \%$ level.

\begin{tabular}{|c|c|c|}
\hline \multirow{2}{*}{$\begin{array}{l}\text { Explanatory } \\
\text { Variable } \\
\end{array}$} & \multicolumn{2}{|c|}{ Model } \\
\hline & (1) & (2) \\
\hline Discretionary Accruals & $\begin{array}{r}-0.1210 \\
(-0.56)\end{array}$ & $\begin{array}{l}-0.2490 \\
(-1.32)\end{array}$ \\
\hline Dispersion of Analyst Estimates & $\begin{array}{c}0.0590 \\
(0.36)\end{array}$ & $\begin{array}{l}-0.0100 \\
(-0.15)\end{array}$ \\
\hline Earnings Surprise & $\begin{array}{l}-0.0340 \\
(-0.52)\end{array}$ & $\begin{array}{l}-0.0610 \\
(-1.11)\end{array}$ \\
\hline Log(MktCap) & $\begin{array}{c}12.5930 * * * \\
(31.33)\end{array}$ & $\begin{array}{c}12.0940 * * * \\
(39.27)\end{array}$ \\
\hline Market / Book & $\begin{array}{c}-0.4780 * * * \\
(-6.55)\end{array}$ & $\begin{array}{c}-0.2380 * * * \\
(-5.41)\end{array}$ \\
\hline Momentum & $\begin{array}{c}-0.0040 * * * \\
(-4.00)\end{array}$ & $\begin{array}{c}-0.0040 * * * \\
(-4.00)\end{array}$ \\
\hline Price / Earnings & $\begin{array}{c}-0.0050 * * \\
(-2.50)\end{array}$ & \\
\hline $\mathrm{N}$ & 39,466 & 54,020 \\
\hline $\mathrm{R}^{2}$ & 0.84 & 0.84 \\
\hline
\end{tabular}




\section{Table VII}

\section{Estimation of the Share Loan Supply Curve}

Table VII shows the results of the second stage regressions of loan fee, $F$, on quantity, $Q$ according to the model:

$$
F=\alpha+\beta_{1} \hat{Q}+\beta_{2} \hat{Q}^{2}+\beta_{3} \text { fedfunds }+\varepsilon
$$

where $\hat{Q}$ is the fitted value of $Q$ from the first stage regression. The regressions are done individually for each of the 930 firms in the sample, and we present the crosssectional mean and median of the resulting estimates. The T-Test $p$-values are calculated using Fama and MacBeth (1973) style T-statistics, while the Wilcoxon $p$ values are calculated using a Wilcoxon signed-rank test. The final column contains the $p$-values from a Fisher chi-square test of the $p$-values from the second stage regression. $* * *$ indicates significance at the $1 \%$ level, $* *$ indicates significance at the $5 \%$ level, and * indicates significant at the $10 \%$ level.

\begin{tabular}{|c|c|c|c|c|c|}
\hline Explanatory Variable & $\begin{array}{c}\text { Mean } \\
\text { Coefficient } \\
\text { Estimates } \\
\end{array}$ & $\begin{array}{c}\text { Median } \\
\text { Coefficient } \\
\text { Estimates } \\
\end{array}$ & $\begin{array}{c}\text { T-Test } \\
\text { P-Value } \\
\end{array}$ & $\begin{array}{l}\text { Wilcoxon } \\
\text { P-Value }\end{array}$ & $\begin{array}{c}\text { Fisher } \\
\text { Test } \\
\text { P-Value } \\
\end{array}$ \\
\hline$\alpha$ (Intercept) & 0.0402 & -0.0986 & 0.85 & $0.00^{* * *}$ & $0.00^{* * *}$ \\
\hline$\beta_{l}$ (Quantity) & 0.4942 & -0.0668 & 0.23 & $0.04 * *$ & $0.00 * * *$ \\
\hline$\beta_{2}$ (Quantity Squared) & 1.0755 & 0.0270 & $0.06^{*}$ & $0.00^{* * *}$ & $0.00 * * *$ \\
\hline$\beta_{3}$ (Federal Funds Rate) & 0.1085 & 0.0469 & $0.01 * * *$ & $0.00^{* * *}$ & $0.00^{* * *}$ \\
\hline
\end{tabular}




\section{Table VIII}

\section{Cross-sectional Sensitivity of Share Loan Supply Curve to Firm Characteristics}

The coefficients estimates from Table VII are regressed on various firm characteristics in order to analyze the sensitivity of the lending market to individual firm traits. $\log (\mathrm{MktCap})$ is the $\log$ of market capitalization from CRSP. The Number of Small (Large) Lender Relationships variable represents the mean number of small (large) lenders who dealt in a particular stock over the entire sample period. Analyst Dispersion is discussed in Section II.D of the text. Bid - Ask Spread is measured as a percentage of the closing mid-price on each day. Institutional Holdings are from the CDA/Spectrum 13f Institutional Holdings database. T-statistics are below the reported parameter estimates in italics and were calculated using standard errors clustered at the firm level. *** indicates significance at the $1 \%$ level, $* *$ indicates significance at the $5 \%$ level, and * indicates significant at the $10 \%$ level.

\begin{tabular}{|c|c|c|c|c|c|c|c|}
\hline $\begin{array}{l}\text { Dependent } \\
\text { Variable } \\
\end{array}$ & Intercept & Log (MktCap) & $\begin{array}{c}\text { Number of } \\
\text { Small Lenders }\end{array}$ & $\begin{array}{c}\text { Number of } \\
\text { Large Lenders }\end{array}$ & $\begin{array}{c}\text { Analyst } \\
\text { Dispersion } \\
\end{array}$ & $\begin{array}{c}\text { Bid - Ask } \\
\text { Spread } \\
\end{array}$ & $\begin{array}{c}\text { Institutional } \\
\text { Holdings }\end{array}$ \\
\hline \multicolumn{8}{|c|}{ Panel A: All Firms } \\
\hline$\alpha($ Intercept $)$ & $\begin{array}{c}9.4774^{*} \\
(1.80)\end{array}$ & $\begin{array}{c}-0.4308 * \\
(-1.92)\end{array}$ & $\begin{array}{c}1.641 * * \\
(2.23)\end{array}$ & $\begin{array}{r}-0.4207 \\
(-0.89)\end{array}$ & $\begin{array}{c}0.5555 \\
(0.81)\end{array}$ & $\begin{array}{c}-8.6155^{* * *} \\
(-2.92)\end{array}$ & $\begin{array}{c}-1.6104 \\
(-1.36)\end{array}$ \\
\hline$\beta_{1}(Q t y)$ & $\begin{array}{c}-10.4564 \\
(-1.03)\end{array}$ & $\begin{array}{c}0.2743 \\
(0.63)\end{array}$ & $\begin{array}{c}2.5089 * \\
(1.76)\end{array}$ & $\begin{array}{c}0.4403 \\
(0.48)\end{array}$ & $\begin{array}{r}-1.9287 \\
(-1.45)\end{array}$ & $\begin{array}{l}5.8208 \\
(1.02)\end{array}$ & $\begin{array}{c}-3.4860 \\
(-1.52)\end{array}$ \\
\hline$\beta_{2}\left(Q t y^{2}\right)$ & $\begin{array}{c}-12.4419 \\
(-0.88)\end{array}$ & $\begin{array}{l}0.2725 \\
(0.45)\end{array}$ & $\begin{array}{c}3.0912 \\
(1.56)\end{array}$ & $\begin{array}{l}1.6262 \\
(1.29)\end{array}$ & $\begin{array}{c}-1.4025 \\
(-0.76)\end{array}$ & $\begin{array}{l}9.3003 \\
(1.18)\end{array}$ & $\begin{array}{c}-6.9357 * * \\
(-2.18)\end{array}$ \\
\hline$\beta_{3}$ (Fed Funds) & $\begin{array}{c}-1.2162 \\
(-1.23)\end{array}$ & $\begin{array}{c}0.0172 \\
(0.41)\end{array}$ & $\begin{array}{c}0.0242 \\
(0.18)\end{array}$ & $\begin{array}{c}0.1446 \\
(1.64)\end{array}$ & $\begin{array}{c}-0.2369 \\
(-1.84)\end{array}$ & $\begin{array}{l}2.4150 \\
(4.38)\end{array}$ & $\begin{array}{r}0.1722 \\
(0.78)\end{array}$ \\
\hline \multicolumn{8}{|c|}{ Panel B: Small Firms } \\
\hline$\alpha($ Intercept $)$ & $\begin{array}{c}17.6450 \\
(0.56)\end{array}$ & $\begin{array}{r}-1.0155 \\
(-0.70)\end{array}$ & $\begin{array}{c}4.1132 * \\
(1.92)\end{array}$ & $\begin{array}{r}-0.4637 \\
(-0.42)\end{array}$ & $\begin{array}{c}0.3646 \\
(0.28)\end{array}$ & $\begin{array}{c}-14.4918^{* *} \\
(-2.18)\end{array}$ & $\begin{array}{c}-1.5880 \\
(-0.50)\end{array}$ \\
\hline$\beta_{1}(Q t y)$ & $\begin{array}{c}14.9330 \\
(0.43)\end{array}$ & $\begin{array}{c}-0.5915 \\
(-0.37)\end{array}$ & $\begin{array}{c}-0.7606 \\
(-0.32)\end{array}$ & $\begin{array}{c}-0.1170 \\
(-0.10)\end{array}$ & $\begin{array}{c}-2.3419 * \\
(-1.65)\end{array}$ & $\begin{array}{r}9.1815 \\
(1.26)\end{array}$ & $\begin{array}{l}-2.7067 \\
(-0.77)\end{array}$ \\
\hline$\beta_{2}\left(Q t y^{2}\right)$ & $\begin{array}{c}42.2160 \\
(0.94)\end{array}$ & $\begin{array}{c}-2.1378 \\
(-1.03)\end{array}$ & $\begin{array}{c}1.3074 \\
(0.42)\end{array}$ & $\begin{array}{l}2.1076 \\
(1.34)\end{array}$ & $\begin{array}{c}-1.3543 \\
(-0.73)\end{array}$ & $\begin{array}{c}10.3115 \\
(1.08)\end{array}$ & $\begin{array}{c}-9.8274 * * \\
(-2.13)\end{array}$ \\
\hline$\beta_{3}($ Fed Funds $)$ & $\begin{array}{l}0.6455 \\
(0.11)\end{array}$ & $\begin{array}{c}-0.0842 \\
(-0.31)\end{array}$ & $\begin{array}{r}-0.2381 \\
(-0.60)\end{array}$ & $\begin{array}{l}0.1844 \\
(0.90)\end{array}$ & $\begin{array}{c}-0.2490 \\
(-1.04)\end{array}$ & $\begin{array}{c}4.0812 * * * \\
(3.30)\end{array}$ & $\begin{array}{c}0.5835 \\
(0.98)\end{array}$ \\
\hline
\end{tabular}




\begin{tabular}{|c|c|c|c|c|c|c|c|}
\hline \multicolumn{8}{|c|}{ Table VIII (continued) } \\
\hline $\begin{array}{l}\text { Dependent } \\
\text { Variable } \\
\end{array}$ & Intercept & Log(MktCap) & $\begin{array}{c}\text { Number of } \\
\text { Small Lenders }\end{array}$ & $\begin{array}{c}\text { Number of } \\
\text { Large Lenders }\end{array}$ & $\begin{array}{c}\text { Analyst } \\
\text { Dispersion } \\
\end{array}$ & $\begin{array}{c}\text { Bid - Ask } \\
\text { Spread } \\
\end{array}$ & $\begin{array}{c}\text { Institutional } \\
\text { Holdings }\end{array}$ \\
\hline \multicolumn{8}{|c|}{ Panel C: Medium Firms } \\
\hline$\alpha($ Intercept) & $\begin{array}{r}8.4954 \\
(1.16)\end{array}$ & $\begin{array}{c}-0.3590 \\
(-1.06)\end{array}$ & $\begin{array}{r}0.4189 \\
(1.14)\end{array}$ & $\begin{array}{c}0.0994 \\
(0.44)\end{array}$ & $\begin{array}{r}0.3519 \\
(0.79)\end{array}$ & $\begin{array}{l}-2.0915 \\
(-1.30)\end{array}$ & $\begin{array}{c}-2.1531 * * * \\
(-3.64)\end{array}$ \\
\hline$\beta_{1}($ Qty) & $\begin{array}{c}64.6458 * * \\
(2.02)\end{array}$ & $\begin{array}{c}-3.3540 * * \\
(-2.28)\end{array}$ & $\begin{array}{c}2.9736 * \\
(1.85)\end{array}$ & $\begin{array}{l}1.0311 \\
(1.05)\end{array}$ & $\begin{array}{r}-0.7081 \\
(-0.37)\end{array}$ & $\begin{array}{c}-5.1535 \\
(-0.73)\end{array}$ & $\begin{array}{c}-0.1450 \\
(-0.06)\end{array}$ \\
\hline$\beta_{2}\left(Q t y^{2}\right)$ & $\begin{array}{c}5.6992 \\
(0.31)\end{array}$ & $\begin{array}{c}-0.1280 \\
(-0.15)\end{array}$ & $\begin{array}{c}-0.9200 \\
(-0.99)\end{array}$ & $\begin{array}{r}-0.3161 \\
(-0.56)\end{array}$ & $\begin{array}{c}-0.3400 \\
(-0.31)\end{array}$ & $\begin{array}{c}-1.3465 \\
(-0.33)\end{array}$ & $\begin{array}{c}0.7035 \\
(0.47)\end{array}$ \\
\hline$\beta_{3}($ Fed Funds $)$ & $\begin{array}{r}2.6187 \\
(0.95)\end{array}$ & $\begin{array}{c}-0.1490 \\
(-1.18)\end{array}$ & $\begin{array}{c}0.1490 \\
(1.08)\end{array}$ & $\begin{array}{r}0.0387 \\
(0.46)\end{array}$ & $\begin{array}{c}-0.0619 \\
(-0.37)\end{array}$ & $\begin{array}{c}0.1968 \\
(0.33)\end{array}$ & $\begin{array}{r}0.3243 \\
(1.46)\end{array}$ \\
\hline \multicolumn{8}{|c|}{ Panel D: Large Firms } \\
\hline$\alpha$ (Intercept) & $\begin{array}{c}-5.4580 \\
(-0.66)\end{array}$ & $\begin{array}{l}0.4240 \\
(1.23)\end{array}$ & $\begin{array}{l}0.4134 \\
(0.49)\end{array}$ & $\begin{array}{c}-1.5176^{* * *} \\
(-1.97)\end{array}$ & $\begin{array}{l}0.3220 \\
(0.21)\end{array}$ & $\begin{array}{r}-0.0617 \\
(-0.01)\end{array}$ & $\begin{array}{c}-1.2174 \\
(-0.87)\end{array}$ \\
\hline$\beta_{I}(Q t y)$ & $\begin{array}{r}-17.469 \\
(-0.54)\end{array}$ & $\begin{array}{c}0.6223 \\
(0.46)\end{array}$ & $\begin{array}{c}4.1878 \\
(1.26)\end{array}$ & $\begin{array}{c}0.0738 \\
(0.02)\end{array}$ & $\begin{array}{c}0.3484 \\
(0.06)\end{array}$ & $\begin{array}{r}-2.7525 \\
(-0.13)\end{array}$ & $\begin{array}{c}-7.8744 \\
(-1.43)\end{array}$ \\
\hline$\beta_{2}\left(Q t y^{2}\right)$ & $\begin{array}{c}-27.4668 \\
(-0.55)\end{array}$ & $\begin{array}{l}0.2701 \\
(0.13)\end{array}$ & $\begin{array}{c}6.3016 \\
(1.23)\end{array}$ & $\begin{array}{l}5.1679 \\
(1.10)\end{array}$ & $\begin{array}{c}-0.7523 \\
(-0.08)\end{array}$ & $\begin{array}{c}-6.5398 \\
(-0.20)\end{array}$ & $\begin{array}{c}-9.2254 \\
(-1.09)\end{array}$ \\
\hline$\beta_{3}($ Fed Funds $)$ & $\begin{array}{r}1.2987 \\
(1.27)\end{array}$ & $\begin{array}{c}-0.0857 * * \\
(-1.99)\end{array}$ & $\begin{array}{c}0.0612 \\
(0.59)\end{array}$ & $\begin{array}{c}0.2595 * * * \\
(2.70)\end{array}$ & $\begin{array}{c}-0.0390 \\
(-0.20)\end{array}$ & $\begin{array}{c}-0.3163 \\
(-0.47)\end{array}$ & $\begin{array}{c}-0.1638 \\
(-0.94)\end{array}$ \\
\hline
\end{tabular}

